\title{
NOTES ON SOURCES, TRANSLITERATIONS AND TRANSLATIONS
}

1. Citations of Mishnah, Talmud and aggadic works are from standard printed editions, most of which have been downloaded from the Bar Ilan Responsa Project Data Base. If there are significant variants, the text may be presented according to a particular manuscript as noted and variants from other witnesses may be presented in an apparatus or in a note. Occasionally line numbers and punctuation are added. Tosefta citations are from Lieberman where available and otherwise from Zuckermandel.

2. Citations from Targum Onkelos and the Targumim to the Prophets and the Hagiographa are from the Yemenite Tag' (תאג). Citations from Targum Pseudo-Jonathan are from E. G. Clarke, 1984. Citations from Targum Neofiti are from A. Diez Macho, 1970. Citations from the Samaritan Targum are from A. Tal, 1988.

3. Hebrew transliteration is based on the "non-technical" system cited in Encyclopedia Judaica, 1972, Vol. 1. Exceptions are made for some commonly used words, particularly names (e.g. Moses, Akiva, etc.). When a vowel combination is not a diphthong but two separate syllables, I have indicated such by use of an apostrophe. I have also included a dot under the " $h$ " (h) to indicate the letter $n$.

4. Transliterations of the Mesopotamian law collections are taken from M. Roth, 1995. Akkadian transliteration uses the Thames font developed by Dr. J. Hoch of the Department of Near and Middle Eastern Civilizations at the University of Toronto. Cunieform texts 
from Babylonian tablets are cited using the abbreviations in W. von Soden (cited as $A H W$ ) and the Chicago Assyrian Dictionary (cited as $C A D)$.

5. Unless otherwise indicated, English translations of Hebrew, Aramaic, and Akkadian texts are my own.

6. Citations from the Septuagint are taken from the Göttingen edition where available. English translations of the Septuagint passages are taken from L. Brenton, 1986. Quotations from the work of Philo and Josephus and translations thereof are taken from the Loeb Classical Library editions.

D.K. 